trouble, of course, is not merely that of defining what is meant by nuclear aggression but also the simple knowledge, which all the non-nuclear powers must share, that no amount of public declaration in the United Nations can provide a kind of universal guarantee. What chance is there, for example, that the great powers would risk an all-out conflict with mainland China in retaliation for the use of nuclear weapons on the border with India?

In some curious sense, however, the issue of military security as such has come to play a quite small part in the objections of the non-nuclear powers to the treaty. To judge from the course of the discussions in Geneva, the less tangible issues of status and sovereignty matter more. Nations such as Indiathe government of which must be given a serious hearing when it says that it has no intention of making nuclear weapons-are affronted that they should be asked permanently to join a group of permanently disadvantaged nations. It would be sensible if the nuclear powers would recognize that the only sure way of winning approval for the treaty in the next few weeks would be some meaningful concession to the smaller powers on the simple issue of the imbalance within the treaty. To expect a cut-off of military production is probably at this stage too much to ask for, but is it entirely unreasonable to ask that the nuclear powers should make regular public declarations of how much fissile material they manufacture each month, for military as well as for civilian purposes? And would it be entirely out of the question that the safeguards procedures now being worked out at Vienna should apply to the nuclear powers as well as to their weaker neighbours?

The consequences of failure could be quite considerable. Now that the draft treaty has found its way to New York, it is bound to seem a defeat for liberal causes if it is returned again to the Disarmament Sub-committee in Geneva. Quite possibly, the treaty and its sensible objectives would not survive such a move. But the non-nuclear powers must recognize that once the treaty has been approved in the Gcneral Assembly, and thrown open to the accession of all and sundry, it will be virtually impossible to stand aloof. For in its present form the treaty includes the provision that states which adhere to the treaty will not supply fertile or fissionable material "to any non-nuclearweapon state for peaceful purposes unless the source or special fissionable material shall be subject to the safeguards ...." In other words, since Britain, the Soviet Union and the United States are certain to sign the treaty, nations wishing not to sign will have to face the prospect of cutting off trade in nuclear materials from the three nations now most heavily engaged in it. Because it is improbable that France and China between them could take over the parts now being played by the established nuclear powers, the chances are that most nations will be compelled to sign on the dotted line once the General Assembly has said yes. (It will nevertheless be extremely interesting to see what, if anything, the French delegation has to say when its turn to speak arrives. France has sent its representatives to the talks in Geneva, but the French Government may well decide it is impossible now to stay aloof.) Caught between the devil and the deep blue sea, it is not surprising that there is now among the non-nuclear powers a growing body of opinion in favour of a postponement of the debate on the nonproliferation treaty at least until the meeting of nonnuclear powers due to be held at Geneva later this year. The nuclear powers are probably right in saying that the problem is too urgent to be postponed yet again, but it is extremely hard to see how they can at this stage blame anybody but themselves.

\section{GPO on the Defensive}

The British General Post Office is busy organizing a "telephone fortnight" in an attempt to silence the public criticism of its services. So far, the promotion has given everybody a chance to tell their favourite telephone stories, most of them unflattering to the GPO. The GPO's timing was inept; it is only two weeks since it announced increases in postal and telephone charges, and it might have been better to let the hubbub settle down before organizing the campaign. Two things seem to have caused particular irritation. The GPO has started to charge for the directory enquiry service, a move which might be expected to reduce rather than increase the use of the telephone services. It has also introduced a two-tier postal system, in which letters stamped with a fivepenny stamp are given preference to those stamped with a fourpenny. The fivepenny letter, the GPO says, will definitely arrive within 24 hours of posting; the fourpenny letter may well be delayed by up to a further day. Although the proposal seems harmless enough (and certainly better than simply raising the tariff to fivepence without the option) it has come in for considerable criticism.

But is all this criticism justified ? 'Two reports published within the past year suggest that it is not. The Prices and Incomes Board, which investigated the GPO's claim for price increases, produced a report which was on the whole favourable to the GPO. Increases in manpower productivity in the GPO compare very favourably with those in private industry. The board was also impressed with the efficiency of the GPO and with its high regard for the public interest. The chief criticism in the report was of the costing system of the GPO.

Comparison of the actual services offered by different telephone services in different countries is difficult. In recent years, the best attempt to do this was carried out by Michael Dunn of the Research Institute for Consumer Affairs, in a study for the International Organization of Consumer Unions. This study shows that the cost of the telephone service in Britain is not excessive; it falls roughly into the middle of the range, with Sweden very much cheaper and West Germany very much more expensive. For annual rental and 1,000 local calls, only Sweden, Netherlands and New Zealand were cheaper than the British system, and the cost in the United States was slightly greater than that in Britain. The efficiency of the system in Britain was compared with systems in Norway and New 
Zealand. Norway clearly has the most efficient system -the proportion of unsatisfactory calls for which the system could be blamed was only 3 per cent, against 9 per cent in the UK and 11 per cent in New Zealand. In Britain, trunk calls were twice as likely to go astray as local calls-nearly 20 per cent were unsatisfactory because of the failure of the system. This, the report points out, is not because the equipment is old and out of date-the failure rate on modern exchanges is much the same as that on pre-war exchanges. The fact is that too little equipment has been provided, so that exchanges are often swamped with calls. When this happens, callers get the engaged signal; it seems that about one-third of the engaged signals are caused in this way, the other two-thirds representing genuinely engaged lines.

The only way to get around this difficulty is to supply more new equipment which, the GPO says, means higher telephone charges. The Prices and Incomes Board found that productivity in the telecommunications side of the GPO had been increasing at a rate of more than 8 per cent per year, and was satisfied that no important improvement could be made in time to avoid a price increase. In the next three years, the GPO is intending to spend $£ 1,100$ million on investment in telecommunications; in order to do this, and to make the target return of 8.5 per cent on net assets, increases in prices were inevitable. Subscribers will have to suffer now if they are to get a better system later. In the longer term, the GPO should be wondering how to increase the number of subscribers-compared with other developed countries, Britain still has very few telephones-183 telephones per 1,000 of population in Britain, against 459 in the USA and 440 in Sweden.

\section{Measuring Aptitude}

INVESTIGATION into supplementary predictive information for university admission is the carefully worded. title of the project set up in 1966 by the committee of vice-chancellors to examine academic aptitude tests for university entrants. While various working parties and councils discuss the entire structure of the sixth form curriculum, the vice-chancellors' investigation is an attempt to provide for more education and less cramming under the existing A-level examination system. Academic aptitude tests would provide information for university selectors on candidates' general ability to think effectively and would supplement the assessment of knowledge provided by A-level examinations. In this way the aptitude tests should remove some of the pressure to cram from the A-level courses.

Recommendations for tests of this kind were made in the Robbins report in 1963 and, although the vicechancellors took three years to set up the investigation, in such matters it is a question of better late than never. The project is being financed by grants from the Department of Education and Science and the Schools Council for an initial four year period, and the first tests were made in 1967. The experimental aptitude test being used in the project is based on a multiplechoice, objective type of test developed by Professor R. A. C. Oliver of the University of Manchester. This in turn evolved from tests of this kind which have been used successfully in the United States for 40 years. Numeracy and verbal ability are the two main factors which are assessed. It is hoped that the tests will measure general ability, not facility in particular subjects, and will therefore be useful in assessment of candidates who want to read a subject at university which they have not studied at school. Aptitude for arts or science should also be indicated. Sixth formers who are not very elever but who have had good teaching, and those who are very bright but have not been well taught, are likely to be misjudged if assessed by A-levels alone, so it is hoped that aptitude tests will show them in their true light.

Experiments with tests of this kind are inevitably slow, because the results cannot be judged until the first sixth formers who are tested have finished their university courses. To save on time on the first series, a number of first year undergraduates were tested last October. In all, 37,000 tests were given, although not all the sixth formers are likely to go to university. This year, 20,000 sixth formers who are intending to apply to university will be tested. As a guard against prejudice or contamination of the sample, the results of the tests are being kept entirely confidential. If useful tests can be developed from this project, and the system becomes operational for the whole of Britain, the results will probably be made available to schools as well as to the university selectors. Because the tests do not depend on a syllabus, they could be given at the beginning of the fourth term in the sixth form, and with the help of marking machines the results could be with the university selectors in good time.

The results could be helpful to schools in that teachers would know whether their personal assessments of students are in line with general standards. No definite policy has yet been formulated on the question of whether the sixth former should be told the results of his test. If the tests indicate an aptitude in a particular direction, it would be useful and only fair for candidates to be told their results, for this might affect their choice of university subject. If and when broader curricula are introduced, and the option for arts or science remains open throughout the sixth form, advice on aptitude might be even more welcome than at present. If continuous assessment of pupils by their teachers is introduced instead of A-level examinations, then academic aptitude tests administered by a single body would be one way of maintaining uniformity of standards.

\section{University Statistics}

THe latest volume of statistics collected by the University Grants Committee from universities in Britain (Returns from Universities and University Colleges, 1965-66. Cmnd. 3586, HMSO, £1) is more than twice the price of its predecessor, but, to compensate, it is nearly four times as big-192 pages instead of 54 . These Returns have been published comparatively much later than earlier issues. The 1964-65 statistics, for example, were out by October of the following year. The latest statistics have been delayed by a further six months. This delay, however, may be a result of some changes in the collection of university statistics introduced in the academic year 1965-66. For example, the timing of the count of staff and student numbers was changed so as to bring it into line with the pattern used in all other sectors of educational statistics. In previous years the count took place at the end of the academic year; in 1965-66 the 